\title{
The Co-Constitution of Politeness Implicature in Conversation
}

\author{
Michael Haugh \\ School of Languages and Linguistics, Griffith University, \\ Nathan, QLD 4111, Australia
}

Email:m.haugh@griffith.edu.au

\begin{abstract}
:
The notions of politeness and implicature are key concepts in the field of pragmatics, yet while there has been numerous studies on politeness and implicature phenomena in various languages, there has been much less attention paid to the intersection between politeness and implicature. The notion of 'politeness implicature,' which refers to instances where by virtue of implying something politeness arises, is thus introduced in order to further our understanding of politeness, implicature, and their intersection. An analysis of the ways in which 'politeness implicatures' arise in conversation indicates that they are not simply indirect meanings arising from recognition of speaker intentions by hearers, but rather arise from joint, collaborative interaction between speakers and hearers. It is thus proposed that an account which proceeds from the assumption that emergence or interactional achievement is a key characteristic of communication, namely the Conjoint Co-Constituting Model of Communication [Arundale, Robert, 1999. An alternative model and ideology of communication for an alternative to politeness theory. Pragmatics 9: 119-154; Arundale, Robert, 2005. Pragmatics, conversational implicature, and conversation. In: Fitch, Kristine, Sanders, Robert (Eds.), Handbook of Language and Social Interaction. Lawrence Erlbaum, Mahwah, NJ, pp. 41-63], is better placed to account for the way in which 'politeness implicatures' are anticipated or inferred from the situation as a whole in conversation.
\end{abstract}

\section{Keywords:}

Linguistic politeness, implicature, co-constitution, intention

Biographical note: Michael Haugh is a lecturer in the School of Languages and Linguistics at Griffith University, Brisbane, Australia. His main research interests include pragmatics, intercultural communication and identity. He has published work on politeness and implicature in Journal of Pragmatics, Multilingua, Pragmatics and Intercultural Pragmatics. 
A multitude of different approaches to both politeness and implicature have been proposed in the past thirty-five years, and they constitute two of the key concepts in the field of pragmatics. Yet, while there has been a multitude of studies on politeness and implicature phenomena in various languages, there has been much less attention paid to the intersection between politeness and implicature. Although a large number of researchers have acknowledged that a relationship does indeed exist as first noted by Grice (1967[1989]) and Searle (1975), there are very few approaches that have made any comprehensive or systematic attempt to deal with the nature of this relationship. Drawing from what has been foreshadowed in previous work in this area, including most notably Brown and Levinson (1987) and Leech (1983), it is proposed that the notion of "politeness implicature" be introduced to refer to instances where by virtue of implying something, rather than simply stating it directly, politeness arises. In doing so, it is hoped such a move will shed further light on the complex nature of politeness, implicature, and their intersection.

An investigation of the manner in which politeness implicatures arise in conversation indicates they are not simply indirect meanings that hearers recognise through different means as 'intended' by speakers, a view that arguably follows from the received view of Gricean pragmatics (Grice 1989, Horn 2004, Levinson 1983, 2000), Speech Act Theory (Searle 1969, 1979), or Relevance Theory (Sperber and Wilson 1995), but rather arise from joint, collaborative interaction between speakers and hearers. An alternative approach that proceeds from the assumption that emergence or interactional achievement is a key characteristic of communication in explicating how politeness implicature arise in conversation, namely the Conjoint Co-Constituting Model of Communication (Arundale, 1999, 2004, 2005; Arundale and Good, 2002), is thus utilised in this paper. It is argued that such an approach can account for the manner in which politeness implicatures arise not as the result of inferences made about the intentions of individual speakers by hearers, but rather as the interactional achievements of speaker-hearer dyads. ${ }^{1}$

In this paper, the notion of politeness implicature is first introduced and then distinguished from the view that politeness itself may constitute an implicature. The way in which politeness implicatures go beyond inferences about speaker intentions is then discussed in the next section, preparing the way for a discussion of an alternative approach to understanding how politeness implicatures arise in conversation, namely the Conjoint Co-Constituting Model of Communication. The implications of this approach for both politeness theory and implicature theory are then considered.

\section{The notion of politeness implicature}

The notion of politeness implicature rests on the observation that by implying something one can give rise to politeness, as has been previously noted in the field (Brown and Levinson, 1987; Leech, 1983). ${ }^{2}$ In this paper, a politeness implicature is broadly defined as something implied in addition to what is literally said (Haugh,

\footnotetext{
${ }^{1}$ Since the focus in this paper is on how politeness implicatures arise in conversation the labels 'speaker' and 'hearer' are used for the sake of convenience, but this does not preclude investigation of similar phenomena in other contexts, such as computer-mediated communication or other forms of asynchronous communication where more general terms would be required.

${ }^{2}$ While this paper concentrates on instances where implicatures give rise to politeness, this is not to say that other interpersonal effects of implicatures, such as impoliteness, sarcasm, humour, avoidance of responsibility and so on, are not important as well. Distinguishing between these other interpersonal effects of implicatures, however, is beyond the scope of this paper.
} 
2002), which having been communicated in this way shows what the speaker thinks of the hearer or the speaker, relative to their expectations about what the speaker should show he/she thinks of the hearer or the speaker (Haugh and Hinze, 2003; Haugh, 2003, 2004). In terms of the metalanguage first proposed in Haugh (2002) and Haugh and Hinze (2003), then, by implying something ("A says U and because of this B thinks something else (I) in addition to U that A did not say") the speaker shows what he/she thinks of the hearer or him/herself ("what A thinks of A" or "what A thinks of B") relative to their expectations ("what A should show A thinks of A" or "what A should show A thinks of B"). ${ }^{3}$ Some of the different kinds of politeness that can arise from implicatures can be seen in the examples of politeness implicatures outlined in this section.

In the following example, an attendant at a museum in Tokyo implies that one is not allowed to eat anything there, and by doing so gives rise to politeness. To understand this politeness implicature, certain contextual information is required, such as the fact that the interlocutors are in a museum, the addressee is starting to eat something, eating in public buildings is often not allowed and so on.

(1) Attendant: Mooshiwake-gozai-mas-en...mooshiwake-gozai-mas-en... excuse(Pol)-have-Pol-Neg excuse(Pol)-have-Pol-Neg (I am very sorry...I am very sorry)

Visitor: A', ike-nai? oh acceptable-Neg

(Oh, is this not allowed?)

Attendant: Mooshiwake-gozai-mas-en... excuse(Pol)-have-Pol-Neg (I am very sorry) (Edo-Tokyo museum, Tokyo) ${ }^{4}$

In this example, a woman visiting the Edo-Tokyo museum in Tokyo is sitting down on a seat and beginning to unwrap some food to eat. An attendant at the museum upon seeing the visitor unwrapping the food begins to walk towards her and starts saying mooshiwake gozaimasen (an honorific form of apology). From the apology made by the attendant, her action of walking towards the visitor, and general knowledge about appropriate behaviour in public places in Japan (for example, traditionally it is considered impolite to eat in public in Japan unless it is in a "designated" eating area such as a restaurant or lunch area), the visitor is able to infer that the attendant wants her to know that eating in the museum is not allowed. In other words, the attendant's apology gives rise to an implicature something like Kochira de tabetewa ikemasen ('You are not allowed to eat here'). The fact that an implicature has indeed arisen is evident from her next utterance where she checks the validity of this implicature $(A$ ', ikenai?, 'Oh, this is not allowed?'). The attendant confirms it with another apology which gives rise to an implicature something like Hai, soo desu ('Yes, that's right'). The way in which the implicature arises in this example, therefore, involves an inferential chain in the speaker's and addressee's minds, possibly something in the manner of the following retrospectively constructed chain of inference (although this does not necessarily represent the exact order of actual processing):

\footnotetext{
${ }^{3}$ Where ' $A$ ' refers to the speaker, ' $B$ ' refers to the hearer/addressee, ' $U$ ' refers to the utterance, and 'I' refers to the implicature.

${ }^{4}$ The abbreviations used in the morphological gloss of Japanese examples in this paper are as follows: Cont $=$ contrastive marker; Cop = copula; Hon = honorification; $\operatorname{Imp}=$ imperative; $\mathrm{M}=$ mood marker; Neg = negation; Nom = nominative $;$ Nomi $=$ nominaliser $;$ Past $=$ past tense $; \mathrm{Pol}=$ 'polite form'; Prog = progressive; $\mathrm{Q}$ = question marker; Quot = quotation; Te = 'te-form'; Top = topic marker; $\mathrm{Vol}=$ volitional.
} 
i. An attendant at the museum has apologised to the visitor.

ii. The attendant is going to tell the visitor something with negative implications for the visitor (inference from i).

iii. The visitor is unwrapping some food to eat (background knowledge).

iv. Eating in public places is sometimes not permitted (background knowledge).

$\mathrm{v}$. The visitor may not be permitted to eat food at the museum (inference from iii and iv).

vi. Asking someone one does not know to stop eating requires an apologetic approach (background knowledge).

vii. The attendant is requesting the visitor to stop eating (inference from ii, $v$ and vi).

The implicature arising from the attendant's apologetic approach is thus a request that the visitor stop eating in the museum. ${ }^{5}$

Politeness may arise from this implicature since the attendant shows that she still respects the 'place' or social position of the visitor, which can give rise to politeness in Japanese (Haugh, 2005), despite asking her to stop doing something. ${ }^{6}$ Through this implicature the attendant reduces the illocutionary force of her request (that the visitor stop eating), and also shows her hesitancy in making this request. The visitor consequently thinks the attendant does not disrespect her social position, and since this is in line with social norms for what service people should show they think of visitors, compensatory politeness arises. Compensatory politeness, a type of politeness foreshadowed in the work of Brown and Levinson (1987), arises when one shows one does not think badly of someone else in spite of some utterance or behaviour that could be interpreted as implying one thinks badly of them (Haugh and Hinze, 2003: 1600-1601; cf. Leech, 2005: 8). In this example, the politeness that can potentially arise is compensatory in nature, because the attendant shows that in spite of making this request, she does not think badly of the visitor by implying this request, thereby reducing its illocutionary force.

Politeness can thus arise from this implicature in a chain of inference, which can be retrospectively constructed as follows:

viii. The attendant has not explicitly told the visitor to stop eating, but has only implied this request (inference from i and vii).

ix. An attendant has the right to inform others of rules (background knowledge)

$\mathrm{x}$. The attendant is hesitant about making this request (inference from viii and ix).

xi. An attendant should not force others to do anything (background knowledge).

xii. The attendant wants the visitor to stop eating, but does not want to force the visitor to stop eating (inference from viii and xi).

xiii. The attendant shows she respects the visitor's place as a 'customer' whom she does not know (inference from $x$ and $x i i)$.

xiv. The visitor thinks the attendant respects her place in spite of asking her to stop eating (inference from xiii).

$\mathrm{xv}$. The attendant should show she respects the visitor's place (background knowledge).

\footnotetext{
${ }^{5}$ While this example could also be analysed as an indirect speech act, as suggested by one of the reviewers, this is not a conventional means of making a request in Japanese, and thus the politeness that arises from the "indirect request" cannot be regarded as conventional either. ${ }^{6}$ The request that she stop eating could, of course, have been interpreted as indicating that the attendant did not respect the visitor's social position, and thus politeness would not have arisen. The general demeanour of the both the attendant and the visitor, however, indicated that this implicature did indeed give rise to politeness in this particular instance.
} 
xvi. The attendant shows what she thinks of the visitor is similar to what she should show she thinks of the visitor (inference from xiv and $\mathrm{xv}$ ).

Politeness can arise from the attendant's utterances by virtue of the fact that something has been implied, so the utterance in example (1) constitutes a politeness implicature. While politeness also arises, in this context, from the honorific form of apology used by attendant, particularly when the attendant repeats the apology in the fourth turn, it is also apparent that politeness has arisen by virtue of the way in the attendant implies this request.

In another example of a conversation involving politeness implicature, Suzuki puts down the food she is holding, and thereby implies that she would like Tanaka to accept and eat the food. This humble offer is greeted by an expression of surprise and delight at the food the host is offering by Tanaka, thereby implying that she thinks the food is too good to be described in words.

(2) (Tanaka is visiting Suzuki's house for dinner)

Suzuki: Anoo, kore, honno hitokuchi-na-n-desu kedo... um this really one mouthful-Cop-Nomi-Cop(Pol) but (Um, this is just a taste but...)

Tanaka: Maa, kore wa kore wa... oh this Top this Top

(Ooh, this [is] this [is]) (adapted from Okamoto, 1985: 186)

The host humbly offers some food to her guest by saying that it is not much, and thereby implying she would like Tanaka to take it anyway. This implicature shows Suzuki is not being overly forceful in making the offer (thus showing respect towards the 'place' of Tanaka), and also shows that her offering is too trivial to be taken seriously, so there is no need for Tanaka to feel gratitude or an obligation to repay the favour. In doing so, Suzuki shows she does not think too highly of her 'place', and therefore this implicature can give rise to demeanour politeness, alluded to in Leech's (1983) modesty maxim, where one shows one does not think too highly of oneself (Haugh and Hinze, 2003: 1606).

Her guest responds by expressing surprise and delight at the food being offered. Through this expression of surprise and delight, which leaves the praise left unsaid, it appears that she means to imply the food is too good to describe in words. By implying praise for Suzuki's offering, Tanaka gives the highest praise possible, namely, unsaid praise, and so shows she thinks more highly of Suzuki's 'place' than she might expect, which can give rise to enhancement politeness. This kind of politeness, alluded to by Leech $(1983,2005)$ among others, arises when one shows one thinks well of someone in a situation where not doing so could be interpreted as implying one thinks badly of them, or when one shows one thinks more highly of someone than they might expect in that situation (cf. Haugh and Hinze, 2003: 1605). The notion of politeness implicature thus encompasses situations whereby implying something, politeness can arise. As seen in the examples of politeness implicatures dicussed in this section, this politeness may arise because one shows one thinks well of someone else, or because one shows one does not think too highly of oneself, among other things.

\section{Politeness as an implicature}

In drawing attention to the phenomenon of politeness implicature, however, the issue of whether politeness itself constitutes an implicature naturally arises. This view has been advanced, most notably in Brown and Levinson's theory of politeness, where it 
is claimed that politeness arises from the addressee attributing a 'polite intention' to the speaker in the form of a particularised implicature (Brown and Levinson, 1987: 6, 95; Brown, 1995: 169; Brown, 2001: 11623). The claim that politeness arises in the form of implicatures (that is, the 'politeness as an implicature' view) has been developed in a number of different ways, ranging from Leech $(1983,2003,2005)$ advocating a Politeness Principle to complement the Cooperative Principle, to Kallia's (2004) more recent proposal of a maxim of politeness that is subsumed under the Cooperative Principle, and Terkourafi's $(2003,2005)$ frame-based theory of politeness in which she argues politeness can arise in the form of both particularised and generalised implicatures.

Leech $(1983,2003,2005)$, for example, has proposed politeness arises in the form of implicatures from utterances that are consistent with the "Principle of Politeness" or the "Grand Strategy of Politeness", and more specifically, the politeness maxims (or constraints). The Politeness Principle itself is postulated as a general "constraint on observed in human communicative behaviour, influencing us to avoid communicative discord or offence, and maintain communicative concord" (Leech, 2005: 7), where concord is conceived as participants making as if they are pursuing the same goals through communication. ${ }^{7}$ Following from this, the Grand Strategy of Politeness (formerly the Principle of Politeness, cf. Leech 1983) is defined as follows: "In order to be polite, self communicates meanings which place a high value on what pertains to other, and which place a low value on what pertains to self (or speaker)" (Leech, 2005: 13). The politeness maxims (or constraints as Leech (2005) prefers to call them) subsumed under this include: generosity/tact, approbation/modesty, agreement, sympathy, and obligation (Leech, 1983: 132), to which Leech (2005: 17-18) adds opinion-reticence and feeling-reticence. For example, when offering a guest a drink it is common to ask something like, What would you like to drink? Leech (2005; cf. 1983: 133-134) claims that this gives rise to politeness, as it is in accordance with the "generosity constraint" (that is, place a high value on the other's wants).

In Japanese, however, it is often not considered polite to ask what others want in more formal or impersonal situations, at least not directly. An indirect question such as Sensei, nani ga yoroshii deshoo ka? ('Teacher, what is good [to drink?]') is most likely preferable in a situation where a student is asking his or her teacher at a class party, for example, rather than a direct question about the teacher's wants such as Sensei, nani ga nomitai n desu ka? ('Teacher, what do you want to drink?') (Suzuki, 1989: 60-61; Suzuki, 1997: 63-64). It could be argued that the generosity constraint in this situation in Japanese is clashing with the "tact constraint" (that is, place a low value on S's wants), which the speaker assumes the addressee's response will be constrained by. It thus follows that an indirect offer makes it easier for the addressee to accept the offer (Leech, personal communication). However, it seems somewhat unlikely that a teacher, with a higher status than the student, would necessarily feel constrained by the "tact constraint", at least as far as it is defined by Leech. Instead, it appears these constraints are conceptualized differently in English and Japanese, and thus are in need of some form of culture-specific elaboration. For example, in this situation 'generosity' in English seems to involve, among other things, avoiding imposition by asking directly what others want rather than making assumptions, while 'generosity' in Japanese appears to involve, among other things, showing respect to

\footnotetext{
${ }^{7}$ However, as argued later in this paper (cf. example 9) it is possible for interactants to coconstitute divergence in interpretings in conversations, but this does not necessarily give rise to impoliteness.
} 
the 'place' of others by not making direct reference to their wants, or sometimes even presuming what they want to avoid having to ask. Thus, while these maxims can be adjusted or relaxed according to the language or culture in question, as Leech (2003, 2005) argues, it remains to be seen whether they really can be shown to account for all the different kinds of politeness found across various cultures in their present form. Kallia (2004), in contrast, has expanded upon the 'politeness as an implicature' view in proposing that politeness arises in the same way as (particularised) conversational implicature from the interaction of a 'maxim of politeness' with the other conversational maxims and the Cooperative Principle. The maxim of politeness is formulated as follows:

"Be appropriately polite (i.e. politic in Watts' sense) in form (choice of how) and content (choice of what).

- Submaxim 1: Do not be more polite than expected.

- Submaxim 2: Do not be less polite than expected." (Kallia, 2004: 161) She draws a distinction between politeness arising in the form of a standard (particularised) implicature through observance of the maxim of politeness, which is generally unnoticed, and politeness that arises in the form of a non-standard (particularised) implicature through non-observance (that is, clashes between the maxim of politeness and other conversational maxims, or flouting of the maxim of politeness), which is presumably generally noticed.

Another approach that builds on the 'implicatures of politeness' view is Terkourafi's $(2003,2005)$ frame-based theory of politeness. She claims that politeness generally arises in the form of a perlocutionary effect (that is, the belief that the speaker is polite) that relies on generalised implicature (Terkourafi, 2005: 251). This generalised implicature is not dependent on recognising the intentions of the speaker, following from Levinson's (2000: 22-23) view of generalised (conversational) implicature as constituting a level of utterance-type meaning that lies between sentence and speaker meaning, which arises by drawing upon previous experience with the utterance in question in similar contexts. However, it is claimed that politeness can also arise from inferences about speaker intentions in the form of a particularised implicature in other situations (Terkourafi, 2003: 152-154; Terkourafi, 2005: 251). Thus, what distinguishes Kallia's (2004) 'maxim of politeness approach' from Terkourafi's (2003, 2005) 'frame-based approach' is that Kallia (2004: 151) assumes the generation of politeness always depends on recognising the intentions of the speaker, while Terkourafi claims that the generation of implicatures of politeness is only dependent on recognising speaker intentions in particular contexts.

There is also similarity in these views to the distinction proposed by Haugh (2003) between politeness that is anticipated as opposed to being inferred, depending on the expectations of the interactants about what they think is likely to occur (as opposed to what they think should occur). Politeness is anticipated when the addressee expects the speaker will shows he/she thinks highly of the addressee or does not think too highly of him/herself and so on. Politeness is inferred, on the other hand, when the addressee does not necessarily expect the speaker will show he/she thinks highly of the addressee or not too highly of him/herself and so on (Haugh, 2003: 400). One potential problem facing the 'politeness as an implicature' view, however, is that it seems to confound the concept of implicature with the more general notion of implication. The latter refers to anything that is the consequence of something else. For example, one implication of my choice to do further study was that I did not have the chance to get any full-time work experience until I had finished that study. An implication is thus not the same thing as an implicature. The latter encompasses a 
much narrower conceptual domain, as can be seen in the fact that it would be odd to classify the above example as an implicature. In other words, an implicature can be roughly defined as something else co-constituted by interactants from what is said in a particular context that goes beyond what is said. An implication, on the other hand, encompasses anything that can be anticipated or inferred by the addressee from what is said.

In the same way, one implication of inviting a friend out by saying something like Do you want to have a cup of coffee later? is that I respect my friend, since I leave him the option of refusing by using the form Do you want...? This implication of respect, by which I show concern for my friend's autonomy to choose what he or she likes, is what gives rise to politeness in many varieties of English. However, if one assumes that politeness involves showing what one thinks of others or oneself, among other things, it appears politeness expresses an interpersonal attitude with which we communicate with others rather than any kind of propositional content, and thus arguably does not itself constitute an implicature. Instead, it seems more natural to refer to politeness as being an implication drawn from what is communicated. One key difference between implicatures and implications is only the former tends to be suspendable. In other words, only implicatures can be suspended with the addition of extra information. The closely related test of cancellability has also been found to be a necessary but not sufficient characteristic for indentifying an implicature, since any meaning that is derived inferentially can only arise in particular contexts, and thus can be cancelled (Carston, 1988, 2002). The suspendability test is therefore applied instead to distinguish between implicatures and implications (of politeness). ${ }^{8}$

For example, in the following exchange Peter's response to Sally's invitation indicates via an implicature that he cannot go for a coffee later:

(3) (Peter and Sally have met in the corridor at work)

Sally: Do want to have a cup of coffee later?

Peter: Oh, I'm snowed under at the moment.

Sally: No worries.

This implicature can be suspended, however, if Peter decides to accept the invitation later in the conversation with something like But I can rearrange things, so let's make it this afternoon.

On the other hand, if Peter had made his refusal explicit in the first place, such a suspension is no longer felicitous, as seen in example (4) where Peter's second utterance sounds somewhat contradictory in relation to his first response:

(4) Sally: Do want to have a cup of coffee later?

Peter: Oh, sorry, I can't go today.

Sally: No worries.

Peter: But I can rearrange things, so let's make it this afternoon. ${ }^{9}$

In contrast, implications of politeness are not so easily suspended. In example (3), Peter's response is a potential politeness implicature, as by implying that he cannot accept Sally's invitation and giving a reason, Peter may be interpreted by Sally as showing he still approves of her despite refusing her invitation. Yet even if Peter later

\footnotetext{
${ }^{8}$ This test does not distinguish implications from conventional implicatures, since conventional implicatures are not suspendable either (Sadock, 1978). However, while Levinson (1979, 1983) argues that honorifics cab give rise to politeness via conventional implicatures, the fact that politeness is cancellable (that is, will not arise in every context) while conventional implicatures are not, suggests this is not a tenable claim.

${ }^{9}$ Of course, if Peter makes explicit reference to the fact he initially refused, he can change his mind with something like, Nah, actually, maybe I will go. I need a shot of caffeine.
} 
shows he does not think highly of Sally at all, the fact that he was previously polite is not suspended as his previous politeness contrasts with his later potential impoliteness, as seen in the next example.

(5) Sally: Do want to have a cup of coffee later?

Peter: Oh, I'm snowed under at the moment.

Sally: No worries.

Peter: You know, I wish you would stop asking me for coffees. Can't you get the hint?

The fact that this contrast between his initial potentially polite utterance and latter potentially impolite utterance exists indicates that implications of politeness cannot be suspended in the same way as implicature, and undermines the view that politeness constitutes an implicature.

To be fair, the main reason that neo-Griceans claim that politeness is an implicature, or at least arises from implicatures, probably lies in their assumption that what is communicated by an utterance is exhausted by two categories, what is said and what is implicated. However, this assumption is not tenable, since various phenomena can be observed which cannot easily be categorised as either implicatures or part of what is literally said, including honorifics, implicated entailments, paratactic inferences, speech-act idioms and elliptical expressions. However, if one does not hold to this assumption, then the problems arising from conceptualising politeness itself as an implicature naturally disappear.

As this discussion has indicated, while it is debatable whether politeness itself can be considered an implicature, the existence of politeness implicatures (an implicature which gives rise to politeness) is indisputable. In the following section, the fairly common assumption that inferring speaker intentions guides the generation of implicatures in conversation is questioned in light of the phenomenon of politeness implicature.

\section{Politeness implicature and speaker intentions}

The notion of implicature has been closely associated with the intentions of speakers in most approaches to implicature to date. Implicatures are generally defined in terms of what the speaker intends to implicate or what the hearer thinks the speaker intends to implicate. Exceptions to this generalisation include Levinson's (2000) claim that generalised implicature is an example of utterance-type meaning as opposed to speaker meaning, and thus does not involve inferring speaker intentions, and Davis' (1998) distinction between speaker implicature (which is dependent on recognising speaker intentions) and sentence implicature (which is not, but rather involves conventionality). However, this view has been critiqued by both other neo-Griceans (Bach, in press; Horn, 2005) and relevance theorists (Carston, 2004a, 2004b), who argue this intermediate level of meaning is unnecessary. In any case, no matter what the conclusion to this debate, the fact remains that Levinson and Davis still claim that speaker intentions underlie the communication of at least some implicatures, and it is this latter claim which is examined in this section.

The reliance on the concept of speaker intention in defining implicature is a consequence of neo-Griceans (Levinson, 1983, 2000) and relevance theorists (Sperber and Wilson, 1995) generalising Grice's original definition of speaker meaning to communication in general. While Grice himself did not necessarily intend this move, as Arundale (1991) argues in his careful analysis of Grice's original writings, the received view which has developed is that implicatures arise from the communication 
of speaker meaning, where a speaker meant $\mathrm{mn}_{\mathrm{mn}}$ something by $x$ if and only if $\mathrm{S}$ "...intended the utterance of $x$ to produce some effect in an audience by means of the recognition of this intention..." (Grice, 1989: 220). Under this view, inferences which do not rely on attributing intentions to speakers are not considered to generate implicatures. $^{10}$

One problem with this view, however, is that it confounds "speaker meaning" with "hearer meaning." What a speaker (intends to) mean is not necessarily what the hearer actually comes to understand (cf. Davis, 1998: 122). This is because how an implicature is understood by hearers is just as important as what the speaker might have "intended" in terms of what implicature arises in an interaction, a point echoed in relation to indirect communication in general in work in speech act theory (Cooren, 2000, 2005; Sbisà and Fabbri, 1980; Sbisà, 1992, 2001), conversation analysis (Bilmes 1993; Heritage, 1990/91; Hopper, 2006), social psychology (Clark, 1996, 1997), and discursive psychology (Edwards, 1997; Potter, 2006). For example, I may write a letter for a student for what I think is a reference for a philosophy job and write that he or she is good at typing with the intention of implying he is unsuitable for the job. However, if the reference turns out to be for a typing job, I fail to imply he or she is unsuitable for the job, and in fact do quite the opposite (Saul, 2002a: 230). The combined effect of the speaker and the hearer on whether or not an implicature arises, or the content of the implicature if it does, has not been sufficiently acknowledged in previous approaches to implicature as Saul (2002b: 370) points out. Moreover, clearly a speaker cannot expect a hearer to understand he/has meant just any implicature. For an implicature to arise in an interaction what is implied must be available to the hearer. Thus, if my friend were to say "I feel sick," I cannot imply that he or she can get help from doctors on a flying saucer simply by saying "A flying saucer is nearby," contrary to Davis' (1998: 74) argument, because the background assumptions required to draw relevant inferences from this response are not likely to be available to my friend. For an implicature to arise, what the speaker implied and what the hearer understood to be implied must be co-constituted, taking into account both the speaker's and the hearer's perspectives.

A second problem relates to the complex, undifferentiated nature of the notion of intention. While speaker intention forms the cornerstone of a number of approaches to implicature in pragmatics, it is not often acknowledged that intention is a complex notion that has multiple, interdependent senses. Intentions can encompass: (1) expressing future plans of self (e.g. I'm going to school this afternoon); (2) ascribing future plans to others (e.g. John is going to study Japanese at university next year); (3) describing what oneself or others want to achieve by doing or saying something (e.g. My intention in going to this conference is to better understand the current state of research in this field); and (4) classifying actions as being done with the speaker's awareness of the implications of them (e.g. John intentionally missed class today) (adapted from Gibbs, 1999: 22-23). This complexity is reflected in the intuitions of ordinary speakers of English about what characterises intention. Intuitions about intention were found by Malle and Knobe (1997: 115) to encompass beliefs (thinking about the act and its effects) and desires (hoping to get some result), while intuitions about intentional action were found (ibid: 115) to encompass intention (the desire to perform an action), skill (the ability to carry out the act), and awareness (knowing

\footnotetext{
${ }^{10}$ Saul (2001: 632, 2002a: 237) claims that conversational implicatures need not be meant, and so are not dependent on speaker intentions, but Davis (2005) argues that on closer examination of Grice's work, he did indeed implicitly claim that conversationally implicating something is dependent on recognising speaker intentions.
} 
what one is doing). Yet the complex nature of intention seems at odds with the fact that many of the processes underlying communication are primarily automatic, which means we must entertain the possibility of "non-conscious intentions" (Arundale, 1997: 4), a highly counter-intuitive proposition.

A related issue is that intentions are generally conceptualised as being "private mental states that are formulated before the performance of behavioural acts" (Gibbs, 1999: 23 ), but as argued by numerous scholars in recent years, communication has nonsummative or emergent properties that go beyond the intentional-states of individuals (Arundale, 1999, 2005; Arundale and Good, 2002; Brown and Levinson, 1987: 48; Clark, 1996; Gibbs, 1999). ${ }^{11}$ For example, in the following exchange a politeness implicature involving a request to use the shower first was only co-constituted later on in the conversation and so attributed to a previous utterance.

(6) (Michael is staying at Sirl's house on holiday in London and Michael is going out sightseeing that day. Sirl and Michael have just met outside the bathroom in the morning)

1: Sirl: What time are you leaving this morning?

2: Michael: Oh..., in about an hour I suppose. Are you in a hurry to leave?

3: Sirl: No, no. Just asking.

(2 second pause)

4: Michael: Would you like to use the bathroom first?

5: Sirl: Yeh, sure, if you don't mind.

From Sirl's initial inquiry in turn 1, an implicature something like Can I use the bathroom first is not generated as one might expect in this situation, as can be seen in Michael's response in turn 2 and Sirl's counter-response in turn 3. While Michael's response in turn 2 still leaves room for the interpretation that there has been such an implicature by giving Sirl the opportunity to say he is in a hurry and thus confirm this implicature, Sirl's counter-response in turn 3 seems to block this particular interpretation. However, the pause after Sirl's counter-response indicates that something has been left unsaid, and so Michael makes an offer to Sirl in turn 4 that he use the shower first, thereby attributing an implicature requesting to use the shower first to Sirl's utterance in turn 1, which is subsequently accepted by Sirl (both the attributed implicature and the offer) in turn 5. This implicature may also have given rise to compensatory politeness, as Sirl was showing concern for Michael's autonomy and freedom to be unimpeded in using the bathroom. However, this politeness implicature only emerged from this interaction after a number of turns and was interactionally-achieved by both interactants "sounding each other out" before coming to an agreed interpretation for Sirl's initial utterance.

According to an intention-based explanation of this episode, Sirl's "intention" to imply a request was not recognised by Michael, who appeared to interpret his utterance in turn 1 as constituting a pre-request at most. This would thus be considered an example of miscommunication, as it was only later on in the conversation that Michael appeared to recognise Sirl's supposed "intention". The problem with this explanation is that it classifies an incident, which could be regarded

\footnotetext{
${ }^{11}$ The notion of "collective intentions" or "we-intentions" proposed by Searle (1990) or Tuomela (2005) is a possible solution to the inability of individual intentions to account for the collaborative and non-summative nature of communication, in particular, conversation, but it remains a slippery concept, and it is unclear how it could be really utilised in explicating how communication occurs (for various critiques of the notion of collective intentionality see Fitzpatrick 2003, Meijers 2003, Miiscevic 2003, and Zaibert 2003 in a special issue of the American Journal of Economics and Sociology).
} 
as simply "sounding out" the other person from which a common understanding emerged, as miscommunication (at least according to received neo-Gricean and relevance theoretic views of communication). Moreover, it is difficult to be sure that Sirl really did intend to imply this request with his first utterance, as it is equally likely that Sirl decided he wanted to use the shower first after Michael's offer. There simply is no way of knowing for sure what Sirl's "intention" was in this exchange, as even Sirl himself may not have been able to differentiate between an a priori and an emergent "intention."

A fourth potential problem with defining politeness implicature in terms of speaker intention is that they are not always fixed and determinate prior to an interaction (Clark, 1997). There are many examples of politeness implicature where the intentions of the speaker are not actually clear. An approach to implicature which defines implicatures in terms of speaker intentions cannot easily cope with this kind of situation. In the following example, which was noted down from a conversation reported to the researcher by a third party, the way in which implicatures are jointly constructed by both the speaker and the hearer is illustrated.

(7) (A mother and her daughter are walking down the street towards the train station in Tokyo)

Mother: Mama, hankachi mot-te-ki-ta to omot-ta-n-da kedo... mother handkerchief carry-Te-come-Past Quot think-Past-Nomi-Cop but (I thought I had brought a hankie along but...)

Daughter: [Passes her handkerchief to her mother]

Mother: $A^{\prime}$, doomo.

$(\mathrm{Oh}, \text { thanks })^{12}$

The mother and daughter were walking along the street chatting, when the mother started looking around in her bag and commented on the fact she did not have her handkerchief. This comment was ambiguous as to whether it was addressed to herself (to make a mental note not to forget next time or to express frustration at forgetting and so on), or it was directed at her daughter in the form a requestive hint. There was no way for the daughter to determine what her mother's intention was in making this utterance unless she asked her directly, but even if she had asked her mother, the mother may not even have known herself what her intention was. ${ }^{13}$ Thus the daughter could not have known exactly what the intention of her mother was in producing this utterance, as she herself reflected in relating this incident. Yet an implicature was nevertheless co-constituted, as by passing the handkerchief to her mother, she indicated that she did indeed interpret this utterance as implying a request (something like 'My mother does not have a handkerchief, but she may need one, so I will offer her mine').

The daughter's interpreting of her mother's utterance and her offer of a handkerchief were both accepted by her mother, and thus politeness also appears to have been retrospectively co-constituted through the daughter's response. Politeness can said to have arisen as the mother showed respect towards the 'place' of her daughter by initially not demanding she give up her handkerchief, although an implied request later emerged in the interaction from her utterance. In other words, what the mother showed she thought of her daughter was consistent with what the daughter thought her mother should show she thinks of her, or what Haugh and Hinze (2003: 1604)

\footnotetext{
${ }^{12}$ Thanks to Rie Kibayashi for this example.

${ }^{13}$ Of course with time the mother probably would have been able to ascribe some kind of intention to it, but this would be an intention formed post facto rather than at the time of utterance itself.
} 
term stasis politeness. The politeness arising from the implicature that emerged in this interaction, then, was not predicated on any assumptions by the daughter about the intentions of her mother. But just as implicatures can arise even when the speaker's intentions are not clear, so too can politeness. Enhancement politeness also arose as daughter showed respect to her mother's 'place' through a demonstration of what Fukushima (2004) terms 'attentiveness' (to her mother's needs), which was apparent in the mother's response where she thanked her daughter. However, the key claim here is that politeness itself could not have arisen without the emergence of this implicature in the interaction between the mother and her daughter. But in this example both the production of the utterance by the mother and the daughter's interpreting of that utterance contributed to the emergence of this implicature without any clarity as to what the mother's initial intentions were in making this utterance. This example thus demonstrates that politeness implicatures can emerge even when the intentions of the speaker are not clear. ${ }^{14}$

An intention-based explanation of example (7) would assume that the mother intended to imply a request, and her daughter correctly made an inference about that intention. But according to the person who reported this example, the mother herself did not have this intention, nor was the daughter sure she had it, but when she was given a handkerchief by her daughter, they realized that an implicature had arisen. The daughter thus could not have made an inference about her mother's intention, correct or otherwise. The traditional explanation thus imposes a view that does not reflect what actually happened in this example. The daughter did not make an inference about her mother's intentions, but rather made an inference from the situation as a whole, as did the mother, who may have had to retroactively change her initial interpretating of her first utterance as a consequence of her daughter offering her a handkerchief. Gauker (2001, 2003) and Marmaridou (2000) have thus argued that (most) implicatures can be generated without hearers making inferences about the intentions of the speaker. It appears, then, that in many cases implicatures arise not from inferences made by the hearer about the speaker's intentions, but are anticipated or inferred from what is said in the situation as a whole. An approach to implicature which takes speaker intentions to be central neglects this possibility.

As suggested by numerous anthropologists (for example, Duranti, 1988; Levine, 1984; Ochs, 1984; Rosaldo, 1982), while intentions are an integral part of the "Western" view of communication, the fact they are not found to be important in all cultures, indicates they may not be as important in interactions, including ones in which politeness implicatures arise, as commonly assumed. There remains, therefore, room to consider an alternative approach, which regards speaker intention as just one resource amongst many in producing and understanding politeness implicatures in conversation.

\section{Co-constituting politeness implicature}

\footnotetext{
${ }^{14}$ This example is similar in some respects to one given by Cooren and Sanders (2002: 1062) where someone switches on the computer after a person asks, "Do you know how to switch on this computer?" (as was pointed out by one of the reviewers). In this situation the intention of the person asking is not clear, yet an implicature still arises, as noted by Cooren and Sanders (2002: 1063). However, politeness may not have arisen in this instance, as 'attentiveness' is not as salient to politeness in the presumably North American English context their example is taken from as it is in Japanese.
} 
The approach to politeness implicature outlined in this section draws primarily from Arundale's (1997, 1999, 2004, 2005) Conjoint Co-constituting Model of

Communication. A number of other interactional models of communication have been proposed, such as Clark's (1996) theory of communication as "joint action" or the "sequential inferential paradigm" (Cooren, 2000; Sanders, 1987; Cooren and Sanders, 2002), but what distinguishes Arundale's approach is that he argues that the collaborative and non-summative or emergent characteristics of communication are a consequence of the way in which meanings are conjointly co-constituted by interactants in conversation. The process of conjoint co-constitution is further defined as the manner in which "each participant's cognitive processes in interpreting and designing are responsive to prior, current, or potential contributions the other participants make to the stream of interaction" (Arundale, 2005: 59). While there are many implications for the study of communication arising from this model, its central principles are applied and developed in relation to only one communicative phenomenon in this paper, namely politeness implicature. The process by which politeness implicatures arise in this interactional view of communication is referred to as "co-constitution" to distinguish it from intention-based views of implicature. Politeness implicature are conceptualised in Arundale's Conjoint Co-constituting Model as emerging from dynamic interaction between two or more interlocutors. According to Arundale (1999) communication in general, and hence politeness implicature in particular, should be conceptualised as something "that emerges in dynamic inter-action as participants produce adjacent utterances and in so doing mutually constrain and reciprocally influence one another's formulating of interpretings" (p.126). Politeness implicature must, therefore, be considered from the perspectives of both the provisional meaning that speakers project, and the hearer's provisional interpretings of the speaker's utterance, and how these interpretings become interdependent through the adjacent placement of further utterances in conversation. According to the Conjoint Co-constituting Model of Communication, then, politeness implicatures are co-constituted by interlocutors in the sequential unfolding of interaction.

Arundale's model identifies three conversational principles underlying the coconstituting of interpretations and hence, of politeness implicatures: the Recipient Design Principle (RDP), the Sequential Interpreting Principle (SIP), and the Adjacent Placement Principle (APP) (Arundale, 1999, 2004, 2005; Arundale and Good, 2002). The Recipient Design Principle (RDP) can be used to describe the processes that underlie speaker projections of politeness implicature, while the Sequential Interpreting Principle (SIP) can be employed to describe the processes that underlie hearer interpretings of politeness implicature. However, it is only because participants in interaction assume the Adjacent Placement Principle (APP) that they find their utterances linked to those of the other in sequence. In other words, it is because of the APP that the interdependent nature of co-constitution emerges, where "both persons [are] affording and constraining the other's interpreting and designing" (Arundale, 2005: 59), and that the non-summative nature of politeness implicature becomes apparent. The RDP in conjunction with the SIP and the APP are therefore what underlie the co-constitution of politeness implicature.

The Recipient Design Principle (RDP) holds that there are five inter-linked processes involved in co-constituting politeness implicatures from the speaker's perspective (Arundale, 1999, 2004, 2005; Arundale and Good, 2002). The RDP is defined as follows, although these five processes do not necessarily occur in any particular order: "Speakers frame an utterance to be produced using both expectations invoked in 
their interpreting of another's prior utterance, and recipient interpretings yet to be formulated; they attribute to the future recipient knowledge of certain resources and procedures; they project the interpreting, integrating, and invoking processes the recipient will employ in formulating an interpreting of the utterance to be articulated; they produce the utterance by selecting and articulating utterance constituents; and they presume that their recipients will hold them accountable for their contribution to the conversation" (Arundale, 1999: 135, author's original emphasis)

From this general definition, one can see that there are essentially five important aspects of producing utterances that can give rise to politeness implicature. First, utterances, which may (but not necessarily always) involve some (sub-)conscious plan for what the speaker wants to accomplish by them, are constructed using expectations about conventions or heuristics that have been invoked by the speaker's interpretings of the other interlocutor's previous utterance, and using expectations about conventions or heuristics the speaker thinks will be salient in interpreting the utterance currently being produced. ${ }^{15}$ For example, in producing an utterance that follows an invitation, the convention that a refusal constitutes a dispreferred response becomes salient.

Second, the utterance is produced with the assumption that the hearer will be able to access those conventions or heuristics that have been evoked, and also access salient aspects of the context, including background knowledge. This is only an assumption made by the speaker, and thus there is no suggestion that the speaker definitely knows that the hearer knows these things. Whether or not the hearer does have access to the knowledge salient to drawing a politeness implicature only becomes apparent later on in the discourse, when the current speaker can infer the current hearer's interpretings of the utterance produced by the current speaker, using her interpretings of later utterances produced by the current hearer. This assumption, therefore, does not have the psychological implausibility of "mutual knowledge", which gives rise to the problem of infinite regress (Gibbs, 1999; Lee, 2001). ${ }^{16}$

The third process is where the speaker projects how the hearer will draw a politeness implicature from the utterance that the speaker is producing. This is a reflexive process whereby the speaker predicts: (1) how the hearer will interpret the utterance to be produced and draw a politeness implicature; (2) how the hearer will integrate the politeness implicature into his understanding of the overall flow of the conversation; and (3) what expectations will be invoked by the hearer in drawing this politeness implicature. The speaker designs his/her utterance accordingly from these predictions. It is thus a reflexive process because the utterance produced is based on the politeness implicature the speaker thinks the hearer will infer or anticipate. Of course, while this projection process, as with all the other aspects of Recipient Design, may be a conscious one, it is more often than not largely 'automatic'.

Fourth, the utterance is articulated by the speaker by selecting and using particular linguistic constituents (that is, sounds, words, syntactic structures and so on). In other words, the speaker makes an utterance that gives rise to the projected politeness implicature.

\footnotetext{
${ }^{15}$ Expectations are defined by Arundale (1999: 130) as an individual's anticipation that a known convention or heuristic will be applicable in co-constituting an implicature from current and forthcoming utterances.

${ }^{16}$ For example, for 'A' to count as mutual knowledge, I must know that you know A, you must know that I know that you know A, I must know that you know that I know that you know A and so on ad infinitum.
} 
Fifth, the speaker assumes the hearer will consider the projected politeness implicature as part of what the hearer attributes to the speaker as the speaker's meaning. In other words, the speaker will be held accountable for any further implications of co-constituting this politeness implicature.

However, the way in which a speaker projects how his/her utterance will be interpreted by the hearer is not necessarily always how it is interpreted by the hearer. In cases where the hearer's interpretation differs from the speaker's projection, the speaker must modify his/her interpretation of his/her own utterance in order to maintain the overall flow of the conversation. In the following example, the way in which projected interpretings must be modified to take into account subsequent interpretings is illustrated.

(8) (Kōji and his workmate are talking at a bus stop, and Kōji is smoking)

1: Workmate: Tabako wa nagai koto o-sui-na-n-desu ka? smoking Top long thing Hon-smoke-Cop-Nomi-Cop(Pol) Q (Have you been smoking for a long time?)

2: Kōji: (smiling) Haa, yame-yoo to wa omot-te-ru-n-desu kedo yeah quit-Vol Quot Cont think-Te-Prog-Nomi-Cop(Pol) but (Yeah, I have thought I'll quit, but...)

3: Workmate: (waving his finger)

Tabako no gai... arekore... iroiro...

smoking of damage this and that various [things]

(Smoking is bad for you... it causes various problems...)

4: Kōji: (angrily saying later to his wife)

Kondo koso yameru zo.

soon $M$ quit $M$

(I'm really going to quit this time!) (Ueda, 1998: 33)

Kōji's workmate opens the conversation by asking whether Kōji has been a smoker for a long time in turn 1. Kōji's response in turn 2 to this indicates that Kōji understood his workmate's utterance to be the opening of a conversation (or a preannouncement) sympathizing about how it is difficult to give up smoking, because Kōji smiles as he responds, saying how he has tried to give up smoking. Kōji's response in turn 2, which ends with a trailing-off kedo ('but...'), also implies something more has been left unsaid, such as nakanaka muzukashii desu ne ('It's difficult [for everyone to quit]'), and thus projects a provisional implicature. In this way, Kōji tries to build rapport with his workmate by implicitly generating a feeling they belong to the same group, one in which they sympathise with each other about how hard it is to give up smoking (and yet they still share the pleasure of smoking). Since showing one acknowledges someone as belonging to the same group as oneself (the place one belongs) can give rise to politeness in Japanese (Haugh, 2005), this provisional implicature, in conjunction with what Kōji has said, could have given rise to politeness. In other words, Kōji's response is a provisional politeness implicature. It is provisional in the sense that it is dependent on Köji's interpreting of his workmate's utterance in turn 1 as a pre-announcement to a conversation where they commiserate about the difficulties of giving up smoking.

However, his workmate's next utterance in turn 3 goes on to make very critical comments about smoking, and so it becomes apparent that Kōji's provisional interpreting of his workmate's utterance in turn 1 as a pre-announcement to a conversation where they sympathise with each other is not consistent with his workmate's own interpreting of this utterance. His workmate's utterance in turn 1 thus emerges as a pre-announcement to a criticism of smoking. In other words, his 
workmate was actually trying to lead into criticism about smoking with this utterance. By going on to criticize Kōji for his smoking habit his workmate shows he does not accept Kōji's interpreting of his utterance turn 1, and thus does not take notice of the politeness implicature arising from Kōji's response in turn 2 . What becomes salient in this conversation, then, is the evils of smoking, not difficulties associated with quitting it, something about which Kōji is unhappy as seen later when he angrily says to his wife he will quit smoking.

Kōji's provisional politeness implicature in turn 2 was based on a particular interpreting of his workmate's utterance in turn 1, but his workmate's subsequent utterance in turn 3 indicates that this interpreting was not accepted, forcing Kōji to revise his interpreting of the utterance in turn 1. In other words, Kōji's provisional politeness implicature became irrelevant to the flow of the conversation as understood by Kōji and his workmate subsequent to his workmate's utterance in turn 3 .

From this example, one can see that even when the speaker thinks something has been implied, an implicature does not necessarily arise straight away in the mind of the other interlocutor. The provisional politeness implicature arising from Kōji's utterance in turn 2 was based on an interpreting of his workmate's utterance in turn 1 that his workmate did not share, and so the provisional politeness implicature was not taken up in his workmate's subsequent utterance, and consequently was not successfully coconstituted. The RDP is therefore not sufficient on its own to describe how implicatures arise. The Sequential Interpreting Principle (SIP), which accounts for the perspective of the hearer, is also required to fully explain how politeness implicatures are co-constituted.

The Sequential Interpreting Principle (SIP) holds that there are three inter-linked processes involved in co-constituting politeness implicature from the perspective of the hearer (Arundale, 1999, 2004, 2005; Arundale and Good, 2002). The SIP is broadly described by Arundale (1999) as the process whereby:

"Recipients interpret the utterance currently being produced by another individual using expectations invoked in producing/interpreting their own prior utterance:

they integrate this current interpreting with their evolving interpreting of the interaction;

and they invoke expectations for another's subsequent interpreting of the recipient's own next utterance (to be used in producing that next utterance)" (p.131, author's original emphasis)

This general principle can be applied to the co-constitution of politeness implicature in the following way. Hearers first draw a provisional implicature from the current utterance using conventions or heuristics that are made salient by the current utterance, and expectations about conventions or heuristics invoked from their interpretating of the prior utterance. They then integrate this provisional implicature into their evolving interpreting of the inter-action as a whole, assessing the degree of consistency between their current interpreting and prior interpretings, and also invoking expectations of particular conventions or heuristics that will be used by the other interlocutor in interpreting the next utterance to be produced by the hearer. This provisional implicature is then ascribed as the speaker's meaning (Arundale, 2004: 7). In other words, the SIP holds that upon hearing a particular utterance, the hearer first uses salient conventions or heuristics to infer or anticipate a provisional implicature. Particular conventions or heuristics are salient because they have been invoked by the hearer's previous utterance, or because they are invoked by the current utterance. For example, in Japanese if a speaker indirectly compliments someone giving rise to a provisional politeness implicature, then the expectation that the other interlocutor will 
down-play this implied compliment becomes salient. This provisional implicature is then integrated into the hearer's understanding of the flow of the conversation as a whole, which may involve some modification of the provisional implicature to give rise to a politeness implicature. From this integrated understanding of the flow of the conversation as a whole, and the place of the politeness implicature within that flow, the hearer then invokes expectations about which conventions or heuristics will be salient for the other interlocutor in interpreting the hearer's next utterance. It follows from the SIP that the communication of politeness implicature is very much a conditional and constantly evolving process, as it depends on the relationship between the provisional implicature in question, and interpretings of past and future utterances. The way in which politeness implicature arises from the SIP is illustrated in the next example where Furiten has forgotten to bring an offering of money (shuugi) to the wedding reception of an acquaintance he is attending.

(9) (Furiten is in line to give his shuugi (a gift of money) at a wedding)

1: Person in front of Furiten:

(as he passes the shuugi to the receptionist)

Omedetoo-gozaimasu

congratulations-Hon(Pol)

(Congratulations!)

2: Furiten: (to himself) A, shimat-ta. Regi wasure-te-ki-ta. oh unfortunate-Past gift forget-Te-come-Past

(Oh, bother! I forgot to bring the gift)

3: Receptionist: Ii-n-desu-no-yo.

Kochira ni o-namae dake de-mo good-Nomi-Cop(Pol)-M-M here to Hon-name only with-even (That's fine! Even if you just [put] your name here...)

4: Furiten: Ii-n-desu $k a$ ? good-Nomi-Cop(Pol) Q (Is that (really) okay?) (Ueda, 1995: 33)

After seeing the person in front of him pass a gift to receptionist who is collecting them on behalf of the couple in turn 1, Furiten says to himself in turn 2 that he has forgotten to bring a gift to the wedding reception. ${ }^{17}$ The fact that he is talking to himself is indicated by the use of the plain form (for example, kita 'came'), which is not appropriate to use in addressing the receptionist collecting the gifts. As Furiten is talking to himself, it is unclear whether or not he is projecting a politeness implicature requesting to sign the guestbook for now even though he has forgotten a gift. Politeness would arise from such an implicature if co-constituted though, as it shows respect towards the 'place' of the receptionist by expressing hesitancy in making such a request that may not be acceptable from the receptionist's point of view. The response of the receptionist in turn 3 indicates that she has indeed formed a politeness implicature, by indicating that it is okay for him to write his name in the book, in spite of the fact that there was no clear projected politeness implicature. In other words, the lady collecting gifts created a politeness implicature without necessarily attributing the intention to Furiten of projecting that implicature. It is only when Furiten responds to the receptionist's offer by checking whether it really is okay to only sign the book in turn 4, that we can see that Furiten and the receptionist both understand a politeness implicature has arisen.

\footnotetext{
${ }^{17}$ While it is clear Furiten had planned to sign the guestbook since he was standing in line, it would not normally be appropriate to sign without having brought a gift. A request to sign the guestbook would thus most likely seem inappropriate in this situation, and thus Furiten is at a loss about what he should do, which could be seen from his visible discomfort with the situation.
} 
From this example, one can see that a politeness implicature is not co-constituted unless both the speaker and the hearer understand an implicature to have arisen. If only the receptionist thinks an implicature has arisen, and thus both interactants are not aware that an implicature has arisen, then a politeness implicature cannot be said to have been co-constituted. Thus, in order to see whether a politeness implicature has indeed been co-constituted, a further conversational principle is required, namely the Adjacent Placement Principle (Arundale, 1999, 2004, 2005; Arundale and Good, 2002).

The Adjacent Placement Principle (APP) claims that it is "the adjacent placement of utterances by each of them that links them in inter-action, each affording and influencing the other's interpretings" (Arundale, 1999: 139). The mutual constraint and reciprocal influences on the individual-based aspects of co-constituting implicatures arising from the RDP and the SIP is what creates the conditionality of interpretatings of implicatures. In other words, the content of a politeness implicature is dependent on both the speaker's projection of what has been implied and the hearer's interpreting of what has been implied, and therefore is always subject to potential revision depending on latter utterances and interpretings made by the interactants. In many cases, the speaker's projected politeness implicature is readily inferred or anticipated by the hearer, but in other cases what has been implied only becomes clear as a conversation progresses.

In example (10), four people are eating and drinking together after work. B seems to want to go home, but appears to be trying to avoid leaving in an abrupt manner, and thus is showing concern towards the 'place' the others belong as a group of relatives and close friends. B's brother is at first reluctant for B to leave, although he eventually seems to accept B's preference. The manner in which these interlocutors influence each other in co-constituting politeness implicatures, as is explained in the APP, is readily apparent, as each interlocutor shows his understanding of what was coconstituted by the previous interlocutor through what he or she says in response. The overall flow of this conversation can thus be clearly seen as a joint product of these four interlocutors, particularly the two brothers.

(10) (B is at drinking his brother's house with his brother, sister-in-law, and another female colleague)

1: B's sister-in-law: Are? nihonshu wa?

$$
\text { oh sake Top }
$$

(Oh! [How about] some sake?)

2: B's brother: A ha ha ha ha, nantoka, odeko, hachi no ji ni

Oh ha ha ha ha somehow forehead eight of letter to na-chat-ta yo, ha ha ha ha become-M-Past $\mathrm{M}$ ha ha ha ha

(Oh ha ha ha ha, your forehead is sort of like the letter eight! Ha ha ha ha)

3: Female colleague: Dame mitai.

no good seems

(It seems he can't take his liquor)

4: B: Un, sake wa chotto ne, un, kyoo kaeri-tai kara...

yeah sake Top a little M yeah today go home-want so

(Yes, sake is a bit, yeah, today I want to go home so...)

5: B's brother: Demo, are, Niigata no wa ne, ii o-sake mitai

but look Niigata Nomi Top M good Hon-sake seems

(But, look, [it is from] Niigata, it seems like a good one)

6: B: Un, soo, nihonshu wa ne, kuchiatari wa suki na-n-desu yo nee. 
yeah so sake Top M taste Cont like Cop-Nomi-Cop(Pol) M M

(Yeah, true, I like the taste of sake)

7: B's brother: Ato ga...

afterwards Nom

([But] afterwards...)

8: B: Uun, ato ga kii-chau-n-desu yo nee.

yeah afterwards Nom smell-M(unfortunate)-Nomi-Cop(Pol) M M

(Yeah, afterwards there are after effects huh?)

9: B's brother: Nioi ga nantoka smell Nom somehow

(The smell sort of...)

10: B: Uun, soo soo, dakara nihonshu wa oishii kedo... yeah right right so sake Cont delicious but

(Yeah, right, right, so sake tastes good, but...) (Uchito, 1997: 31)

In this interaction, there are a number of different politeness implicatures that arise. $\mathrm{B}$ first implies in turn 4 that he will not drink any more sake after seeing his brother being offered more sake by B's sister-in-law in turn 1 (following an intervening comment from his brother in turn 2 and another female colleague commenting on his brother's apparent drunken state in turn 3). He says nihonshu wa chotto ne ('sake is a bit...', which can be further fleshed out by inference to mean something like tsuyoi ('strong'), and kyoo kaeritai kara ('I want to go home today so...') which together imply something like moo nomanai ('I won't drink any more'). By implying a refusal of his sister-in-law's implicit offer, B is able to show concern for her 'place' as a host in this instance by emphasising the reasons for his refusal, and so potentially giving rise to compensatory politeness (by showing he still respects her as the host, even though he is refusing her, which could give rise to the implication he thinks she is not a good host).

However, his sister-in-law's uptake of this politeness implicature in turn 4 cannot be readily observed as B's brother takes over the role of the host by insisting that the sake they are drinking is a very good one in turn 5, thereby implying B should stay a bit longer (another potential politeness implicature as B's brother shows concern towards B's place as part of the group). In this way, while B's politeness implicature was initially directed at his sister-in-law, and thus one would expect her to show interpreting of it through some kind of response, it is B's brother who takes over this role in turn 5 by placing a politeness implicature cajoling B to stay adjacent to B's potentially polite refusal in turn 4 .

$\mathrm{B}$ responds to his brother's cajoling to stay by initiating an exchange where the negative after-effects of drinking sake are discussed. He starts this sequence by saying he likes the taste of sake (nihonshu wa ne, kuchiatari wa suki nan desu yo nee, 'Yeah I like the taste of sake') in turn 6 . The contrastive particle wa following kuchiatari ('taste') is an important trigger for another provisional politeness implicature, because the use of wa in this context means that whatever precedes it should be contrasted with something else. In this utterance, the taste of sake is implicitly contrasted with the after-effects of drinking it. This implicature is used to further support B's desire to stop drinking and go home, and may have given rise to politeness as it once again showed B's reluctance to explicitly say he wants to go home, thereby showing concern towards their mutual feeling of belonging to a group.

The co-constitution of the provisional politeness implicature in turn 6 becomes apparent from the adjacent placement of his brother's incomplete comment about 'afterwards' (ato ga..., '[but] afterwards...') in turn 7. The incomplete comment 
(which is finished by B himself in turn 8 ) indicates his brother has indeed interpreted the utterance in turn 6 as giving rise to a politeness implicature, as he shows he is starting to become sympathetic to the view that the after-effects of drinking too much are not good (and thus it may be okay to let B go home).

After B finishes his brother's previously unfinished utterance in turn 8 (uun, ato ga kiichau n desu yo nee, 'yeah, afterwards there are after-effects huh?'), B's brother shows further acceptance of B's line of thought in turn 9 by indicating that the aftereffects include bad odours the next day (nioi ga, nantoka..., 'the smell sort of...'). The convergence of B and his brother's intepretings of B's utterance in turn 6 as giving rise to a politeness implicature thus become even more apparent by turn 9 . In the final politeness implicature arising in this interaction, B says dakara nihonshu wa oishii kedo ('so sake is delicious but...') in turn 10. This gives rise to another implicature something like moo nomanai hoo ga ii desu ne ("it is better not to drink any more'), which implicitly repeats B's wish to stop drinking and go home. Once again, politeness may have arisen here since B is showing concern towards the group by indicating his reluctance to go home with this implicature (that is, by showing his reason for going home is not that he is unhappy drinking together with them). From this example, the way in which the adjacent placement of utterances is crucial to the co-constitution of politeness implicature becomes salient. In accord with the APP, interactants keep a check on each other's interpretings of politeness implicatures occurring in the conversation. They also modify their interpretings of utterances so that politeness implicature emerge as a joint product of the speaker and the hearer as the conversation progresses.

The way in which the three principles outlined in this section interact can now be illustrated in the following example of a politeness implicature. In this interaction, Furiten implies a request that his colleague not smoke in the car and thereby gives rise to politeness.

(11) (Furiten and his colleague are in Furiten's car. His colleague starts to light a cigarette)

Furiten-kun: A...boku no kurma kinen na-n-da kedo...
Ah I of car non-smoking Cop-Nomi-Cop but
(Ah...my car is 'non-smoking' but...)
Older colleague: Katai koto iu-na yo. Ippon gurai ii ja-nee ka.
strict thing say-Imp(Neg) M one about good Cop(Neg) Q
(Don't be so uptight! One will be okay won't it?)
(Ueda, 1995: 48)

We can now consider the politeness implicature arising from Furiten's utterance from two perspectives, that of the speaker and that of the hearer. From Furiten's perspective (the speaker) a projected politeness implicature arises in the manner outlined in the Recipient Design Principle (RDP). Furiten frames his utterance with the expectation that the fact that his older colleague has started to light a cigarette has been made salient, and attributes to his colleague background knowledge about the acceptability (or not) of smoking in confined spaces, in particular private spaces (as opposed to public spaces). Furiten also projects the interpreting, integrating and invoking processes that his colleague will utilize to give rise to the implicature in question. This process involves the following two projected chains of inference. The second chain of inference (vii-x) is dependent on the first one (i-vi), although this order does not necessarily reflect the actual order in which they are processed, as the two chains could be drawn virtually simultaneously:

i. Furiten has said his car is a non-smoking area. 
ii. Furiten's car is a confined, private space (background knowledge).

iii. Furiten does not like people to smoke in his car (inference from $\mathrm{i}$ and ii)

iv. Furiten's older colleague is starting to light up a cigarette in order to smoke.

v. Furiten does not want his colleague to smoke in his car (inference from iii and iv).

vi. Furiten is asking his colleague not to smoke in his car (inference from i, iv and v).

vii. Furiten has ended his utterance with a trailing-off kedo ('but').

viii. Furiten also means something that contrasts with what precedes kedo

(anticipation from vii).

ix. Furiten makes as if to give options to his colleague other than complying with his request (inference from $\mathrm{i}$ and viii).

$\mathrm{x}$. Furiten is hesitant to make the request in vi (inference from vi and ix).

From these two chains of inference two implicatures arise; namely that Furiten would like his colleague to not smoke in the car, but that he does not necessarily expect his colleague to desist from smoking. Furiten also projects that compensatory politeness may be anticipated from these two interdependent chains of inference in the following way:

xi. Furiten has not said his older colleague should not smoke, but has only implied this request ( $\mathrm{i}$ and vi).

xii. Furiten makes as if to give his colleague options other than complying with his request, and shows he is hesitant about making the request (ix and $\mathrm{x}$ ).

xiii. Furiten shows he respects his colleague higher status (anticipation from xi and xii).

xiv. Furiten's colleague thinks Furiten should show Furiten respects his colleague's higher status (background expectation).

xv. Furiten's colleague thinks Furiten respects his higher status (anticipation from xiii and xiv)

These projected chains of inference and anticipations giving rise to a politeness implicature are realized by the production of the utterance by Furiten, and thus he would expect to held accountable for this politeness implicature.

From the perspective of the Furiten's colleague (the hearer) a provisional politeness implicature arises in the manner outlined in the Sequential Interpreting Principle (SIP). Furiten's colleague interprets Furiten's utterance with the expectation invoked that his action of starting to light a cigarette is salient, and the expectation that Furiten should show Furiten respects his colleague's higher status (or more generally his 'place') since he is a more senior work colleague. Other background knowledge made salient is that Furiten's car is a confined, private space. Furiten's colleague uses these expectations and background knowledge in the inferential chains described above to give rise to a provisional implicature. Politeness may also be anticipated in this situation, since along with Furiten's general demeanour, ending a request with a trailing-off kedo ('but...'), which theoretically leave options open to the hearer, is a common way of showing respect to others in the context of a request in Japanese. Furiten's colleague may thus be able to anticipate Furiten will show respect towards his place as someone senior in this manner, thereby giving rise to politeness. This provisional politeness implicature is then integrated into his understanding of the overall interaction, and used to invoke expectations about the next utterance which he makes. The expectation invoked and thus salient in this conversation is whether or not the colleague is going to comply with Furiten's request he not smoke.

From the colleague's adjacent placement of his response to Furiten's utterance, it 
appears that he has indeed drawn the politeness implicature as projected by Furiten, since his refusal to stop lighting his cigarette presupposes he has been asked not to smoke. In other words, the colleague's complaints only make sense in light of a request being made, and thus the colleague must have attributed this implicature to Furiten's initial utterance (and most likely politeness as well). As explained in the Adjacent Placement Principle (APP), then, a politeness implicature is co-constituted through Furiten's colleague indicating his interpreting of Furiten's initial utterance as an implied request.

However, just because Furiten made his request politely, does not mean he will necessarily achieve his desired outcome. Indeed, Furiten's colleague says that Furiten is being a bit uptight and argues that just one cigarette should be okay. This demonstrates that while the colleague has understood Furiten's request, he does not wish to comply with it. In this way, we can see that while a politeness implicature has indeed arisen in this interaction, Furiten's colleague is trying to re-cast it as an unreasonable (and thus potentially impolite) request in his response. From this attempt to re-cast the interpreting of Furiten's previous utterance, we can also see that the APP involves more than merely confirming the expected projected politeness implicature has indeed arisen. It may also involve re-interpreting of previous utterances (or at least attempting to do so).

It may be noted that in the above discussion of the co-constitution of politeness implicature, the notion of intention has not been referred to. This is not to say that the attribution of intentions is not sometimes involved in drawing politeness implicature. Speakers do presume that they will be held accountable for what they say, as described in the Recipient Design Principle. Moreover, in some instances, particularly where some kind of misunderstanding becomes apparent in a conversation, interactants may use inferences about the intentions of the speaker to reconstruct another possible interpreting (Arundale, 1997; Arundale and Good, 2002). However, unlike other approaches to implicature, the Conjoint Co-Constituting Model does not assume that intentions must always be attributed to speakers for implicatures to be drawn. This is because implicatures are anticipated or inferred from the situation as a whole, rather than arising only from inferences about specific intentions of the speaker. ${ }^{18}$

\section{Concluding remarks}

The notion of politeness implicature has received little attention in the literature thus far, yet the analysis in this paper has indicated that they are an important means by which politeness arises in conversation. A number of weaknesses in (neo-)Gricean and Relevance theoretic approaches in pragmatics, which rely on a view of communication as dependent on the recognition of speaker intentions, have emerged in the course of this analysis. The key problem facing these approaches is that politeness implicatures appear to be more than a result of the summation of inferences about speaker intentions. An analysis of the way in which politeness implicature is interactionally-achieved in conversation has indicated its emergent or non-summative nature. It has thus been argued an alternative approach which does not rest on such an

\footnotetext{
${ }^{18}$ One issue that remains outstanding in this account is the extent to which the co-constitution of politeness implicature relies on inference as opposed to anticipation. It is suggested that Arundale's $(1999,2005)$ "default interpreting principle" (representing anticipation) and "nonce interpreting principle" (representing inference) may be able to account for this distinction, although there is not sufficient room in this paper to further develop this line of argument.
} 
assumption, such as the Conjoint Co-Constituting Model of Communication, may be better placed to provide a more indepth analysis of the emergence of politeness implicatures in conversation. While any number of inferences might be made about what is said in a particular context, whether a politeness implicature arises is delimited by whether it can be said to have been co-constituted in that conversation. In this way, speaker intention is given a less prominent place, and the characteristic emergent nature of politeness implicatures can be accounted for in the conjoint coconstituting approach.

There are numerous implications for both current approaches to implicature and politeness that arise from the line that has been developed in this paper. In regards to politeness theory, it is apparent that furthering our understanding of this complex notion depends, in part, on approaching it from the point of view of a more general theory of communication rather than developing it as a theory in isolation. In other words, those developing theories of politeness needs to carefully examine their underlying assumptions about communication if they are to better explicate this in a comprehensive theory of politeness.

There are also implications for the continuing debate about what constitutes an implicature. Recent debates about implicature between the two main opposing views in pragmatics, namely the neo-Gricean and Relevance theoretic approaches have often centred on the issue of defining the scope of implicature (Bach, in press; Carston, 2005; Horn, 2005), that is, the question of what counts as an implicature and what counts as something else. This debate is often framed as a terminological debate rather than being of significant theoretical import. Carston (2002), for example, concludes in her comprehensive defense of the concept of explicature that "the distinction between explicatures and implicatures, the two kinds of communicated assumptions, is primarily a derivational distinction and may have no greater import than that" (p.366). However, the existence of politeness implicature would suggest otherwise. The fact that by implying something one can give rise to politeness indicates that the implicature is not simply a category to be distinguished on the basis of its derviational process, but rather that implying something sometimes has crucial implications for interpersonal aspects of communication. The controversy as to what constitutes an implicature is thus far from being resolved, and goes beyond being a terminological debate as it has been recently cast.

There remains much work to be done to further our understanding of the relationship between politeness and implicature, not only in languages other than English or Japanese, but also to further our understanding of the inferential processes underlying the way in which they arise in communication. The approach to politeness implicature outlined in this paper is proposed as a possible starting point for such an endeavour. While debates as to how politeness and implicature are communicated will no doubt continue, it is suggested that a greater appreciation of the importance of 'politeness implicature' for this debate may eventually lead to a better understanding of these complex issues.

\section{Acknowledgements}

I would like to express special thanks to Robert Arundale for his very comprehensive and always insightful comments on this paper, and also his encouragement and support, since I first contacted him about his work in 1999. I would also like to thank the two anonymous reviewers for their helpful comments and for pointing out to me tother work in the field that supports the view represented in this paper. All errors or misinterpretations that might be found in this work, however, are entirely my own. 


\section{References}

Arundale, Robert, 1991. Studies in the way of words: Grice's new directions in conceptualizing meaning in conversational interaction. Paper presented at International Communication Association Conference, Chicago, Illinois.

Arundale, Robert, 1997. Against (Grice's) intention. Paper presented at LSI Preconference on Language and Cognition, International Communication Association Conference, Montreal, Quebec, Canada.

Arundale, Robert, 1999. An alternative model and ideology of communication for an alternative to politeness theory. Pragmatics 9: 119-154.

Arundale, Robert, 2004. Co-constituting face in conversation: An alternative to Brown and Levinson's politeness theory. Paper presented at 90th Annual National Communication Association Conference, Chicago, Illinois.

Arundale, Robert, 2005. Pragmatics, conversational implicature, and conversation. In: Fitch, Kristine, Sanders, Robert (Eds.), Handbook of Language and Social Interaction. Lawrence Erlbaum, Mahwah, NJ, pp. 41-63.

Arundale, Robert, Good David, 2002. Boundaries and sequences in studying conversation. In: Fetzer, Anita, Meierkord, Christine (Eds.), Rethinking Sequentiality. Linguistics Meets Conversational Interaction. John Benjamins, Amsterdam, pp. 121-150.

Bach, Kent, in press. The top 10 misconceptions about implicature. In: Birner, Betty, Ward, Gregory (Eds.), Drawing the Boundaries of Meaning. Neo-Gricean Studies in Pragmatics and Semantics in Honour of Laurence R. Horn. John Benjamins, Amsterdam.

Bilmes, Jack, 1993. Ethnomethodology, culture, and implicature: Toward an empirical pragmatics. Pragmatics 3: 387-410.

Brown, Penelope, 1995. Politeness strategies and the attribution of intentions: the case of Tzeltal irony. In: Goody, Esther (Ed.), Social Intelligence and Interaction. Cambridge University Press, Cambridge, pp. 153-174.

Brown, Penelope, 2001. Politeness and language. In: Smelser, Neil, Baltes, Paul (Eds.), International Encyclopedia of the Social and Behavioural Sciences. Elsevier Science, Oxford, pp. 11620-11624.

Brown, Penelope, Levinson Stephen, 1987. Politeness. Some Universals in Language Usage. Cambridge University Press, Cambridge.

Carston, Robyn, 1988. Implicature, explicature, and truth-theoretic semantics. In: Kempson, Ruth (Ed.), Mental Representations: The Interface between Language and Reality. Cambridge University Press, Cambridge, pp. 155-181.

Carston, Robyn, 2002. Thoughts and Utterances. The Pragmatics of Explicit Communication. Blackwell, Oxford.

Carston, Robyn, 2004a. Relevance theory and the saying/implicating distinction. In: Horn, Laurence, Ward, Gregory (Eds.), Handbook of Pragmatics. Blackwell, Oxford, pp. 633-656.

Carston, Robyn, 2004b. Truth-conditional content and conversational implicature. In: Bianchi, Claudia (Ed.), The Semantics/Pragmatics Distinction. CSLI Publications, Stanford, CA.

Carston, Robyn, 2005. Relevance theory, Grice and the neo-Griceans: a response to Laurence Horn's 'Current issues in neo-Gricean pragmatics'. Intercultural Pragmatics 2: 303-319.

Clark, Herbert, 1996. Using Language. Cambridge University Press, Cambridge. 
Clark, Herbert, 1997. Dogmas of understanding. Discourse Processes 23: 567-598.

Cooren, Francois, 2000. The Organizing Property of Communication. John Benjamins, Amsterdam.

Cooren, Francois, 2005. The contribution of speech act theory to the analysis of conversation: How pre-sequences work. In: Fitch, Kristine, Sanders, Robert (Eds.), Handbook of Language and Social Interaction, Lawrence Erlbaum, Mahwah, NJ, pp.21-40.

Cooren, Francois, Sanders, Robert, 2002. Implicatures: a schematic approach. Journal of Pragmatics 34: 1045-1067.

Davis, Wayne, 1998. Implicature. Intention, Convention, and Principle in the Failure of Gricean Theory. Cambridge University Press, Cambridge.

Davis, Wayne, 2005. How normative is implicature? Paper presented at 9th International Pragmatics Association Conference, Riva del Garda, Italy.

Duranti, Alessandro, 1988. Intentions, language, and social action in a Samoan context. Journal of Pragmatics 12: 13-33.

Edwards, Derek, 1997. Discourse and Cognition. Sage, London.

Fitzpatrick, Dan, 2003. Searle and collective intentionality. American Journal of Economics and Sociology 62: 45-66.

Fukushima, Saeko, 2004. Evaluation of politeness: the case of attentiveness. Multilingua 23: 365-387.

Gauker, Christopher, 2001. Situated inference versus conversational implicature. Nous 35: 163-189.

Gauker, Christopher, 2003. Words Without Meaning. MIT Press, Cambridge, Massachusetts.

Gibbs, Raymond, 1999. Intentions in the Experience of Meaning. Cambridge University Press, Cambridge.

Grice, Paul, 1967[1989]. Studies in the Way of Words. Harvard University Press, Cambridge, Massachusetts.

Haugh, Michael, 2002. The intuitive basis of implicature: relevance theoretic implicitness versus Gricean implying. Pragmatics 12: 117-134.

Haugh, Michael, 2003. Anticipated versus inferred politeness. Multilingua 22: 397413.

Haugh, Michael, 2004. Revisiting the conceptualisation of politeness in English and Japanese. Multilingua 23: 85-109.

Haugh, Michael, 2005. The importance of 'place' in Japanese politeness: Implications for cross-cultural and intercultural analyses. Intercultural Pragmatics 2: 41-68.

Haugh, Michael, Hinze, Carl, 2003. A metalinguistic approach to deconstructing the concepts of 'face' and 'politeness' in Chinese, English and Japanese. Journal of Pragmatics 35: 1581-1611.

Heritage, John, 1990/91. Intention, meaning and strategy: observations on constraints on interaction analysis. Research on Language and Social Interaction 24: 311-322.

Hopper, Robert, 2006. A cognitive agnostic in conversation analysis: when do strategies affect spoken interaction? In: te Molder, Hedwig, Potter, Jonathan (Eds.), Conversation and Cognition, Cambridge University Press, Cambridge, pp.134-158.

Horn, Laurence, 2004. Implicature. In: Horn, Laurence, Ward, Gregory (Eds.), Handbook of Pragmatics, Blackwell, Oxford, pp.3-28.

Horn, Laurence, 2005. Current issues in neo-Gricean pragmatics. Intercultural Pragmatics 2: 191-204.

Kallia, Alexandra, 2004. Linguistic politeness: the implicature approach. Multilingua 23: 145-169. 
Lee, Benny, 2001. Mutual knowledge, background knowledge and shared beliefs: their roles in establishing common ground. Journal of Pragmatics 33: 21-44.

Leech, Geoffrey, 1983. Principles of Pragmatics. Longman, London.

Leech, Geoffrey, 2003. Towards an anatomy of politeness in communication. International Journal of Pragmatics 14: 101-123.

Leech, Geoffrey, 2005. Politeness: is there an East-West divide? Journal of Foreign Languages (Shanghai International Studies University) 6: 3-30.

Levine, R., 1984. Properties of culture: an ethnographic view. In: Shweder, R., LeVine, R. (Eds.), Culture theory: Essays on mind, self and emotion. Cambridge University Press, New York, pp. 67-84.

Levinson, Stephen, 1979. Pragmatics and social dexis: reclaiming the notion of conventional implicature. Berkley Linguistics Society 5: 206-223.

Levinson, Stephen, 1983. Pragmatics. Cambridge University Press, Cambridge.

Levinson, Stephen, 2000. Presumptive Meanings. The Theory of Generalised Conversational Implicature. MIT Press, Cambridge, Mass.

Malle, Betram, Knobe, Joshua, 1997. The folk concept of intentionality. Journal of Experimental Social Psychology 33: 101-121.

Marmaridou, Sophia, 2000. Pragmatic Meaning and Cognition. John Benjamins, Amsterdam.

Meijers, Anthony, 2003. Can collective intention be individualized? American Journal of Economics and Sociology 62: 167-183.

Miscevic, Nenad, 2003. Explaining collective intentionality. American Journal of Economics and Sociology 62: 257-267.

Mizutani, Nobuko, 1988. Aizuchi riron [Theory of backchannels]. Nihongogaku 7: 411.

Mizutani, Nobuko, 1999. Kokoro o Tsutaeru Nihongo Kooza [Discussions on conveying heart and mind in Japanese]. Kenkyusha, Tokyo.

Ochs, Elaine, 1984. Clarification and culture. In: Schriffion, Deborah (Ed.), Georgetown University Roundtable on Language and Linguistics. Georgetown University Press, Washington, D. C., pp. 325-341.

Okamoto, Shigeko, 1985. Ellipsis in Japanese Discourse. Unpublished PhD Dissertation. University of California, Berkeley.

Potter, Jonathan, 2006. Cognition and conversation. Discourse Studies 8: 131-140.

Rosaldo, M., 1982. The things we do with words: Ilongot speech acts and speech act theory in philosophy. Language in Society 11: 203-237.

Sadock, Jerry, 1978. On testing for conversational implicature. In: Cole, Peter (Ed.), Syntax and Semantics Volume 9. Pragmatics. Academic Press, New York, pp. 281-297.

Sanders, Robert, 1987. Cognitive foundations of calculated speech. State University of New York Press, Albany, NY.

Saul, Jennifer, 2001. Critical studies: Wayne A. Davis, Conversational Implicature: Intention and Convention in the Failure of Gricean Theory. Nous 35: 630-641.

Saul, Jennifer, 2002a. Speaker meaning, what is said, and what is implicated. Nous 36: 228-248.

Saul, Jennifer, 2002b. What is said and psychological reality: Grice's project and relevance theorists criticisms. Linguistics and Philosophy 25: 347-372.

Sbisà, Marina, 1992. Speech acts, effects and responses. In: Searle, John, Parret, Herman, Verschueren, Jef (Eds.), (On) Searle on Conversation, John Benjamins, Amsterdam, pp.101-111. 
Sbisà, Marina, 2001. Intentions for the other side. In: Gosenza, Giovanna (Ed.), Paul Grice's Heritage. Brepols, Turnhout, pp.185-206.

Sbisà, Marina, Fabbri, Paolo, 1980. Models(?) for a pragmatic analysis. Journal of Pragmatics 4: 301-319.

Searle, John, 1969. Speech acts. Cambridge University Press, Cambridge.

Searle, John, 1975. Indirect speech acts. In: Morgan, P., Cole, J. (Eds.), Syntax and Semantics, Volume 3. Speech Acts. Academic Press, New York, pp.59-82.

Searle, John, 1979. Expression and Meaning. Studies in the Theory of Speech Acts, Cambridge University Press, Cambridge.

Searle, John, 1990. Collective intentions and actions. In: Cohen, P., Morgan, J., Pollack, M. (Eds.), Intentions in communication. MIT Press, Cambridge, Mass, pp. 401-416.

Sperber, Dan, Wilson, Deirdre, 1995. Relevance. Communication and Cognition $\left(2^{\text {nd }}\right.$ edn), Blackwell, Oxford.

Suzuki, Mutsumi, 1989. Kikite no shiteki ryooiki to teinei hyoogen [Personal boundaries of addressees and polite expressions]. Nihongogaku 8: 58-67.

Suzuki, Mutsumi, 1997. Nihongo kyooiku ni okeru teineitai sekai to futsuutai sekai [The worlds of polite and and non-polite forms and Japanese language education]. In: Takubo, Yukinori (Ed.), Shiten to Gengo Koodoo [Perspective and Linguistic Behaviour]. Kuroshio, Tokyo, pp. 45-76.

Terkourafi, Marina, 2003. Generalised and particularised implicatures of linguistic politeness. In: Kuhnlein, Peter, Rieser, Hannes, Zeevat, Henk (Eds.), Perspectives on Dialogue in the New Millennium. John Benjamins, Amsterdam, pp. 149-164.

Terkourafi, Marina, 2005. Beyond the micro-level in politeness research. Journal of Politeness Research 1: 237-262.

Tuomela, Raimo, 2005. We-intentions revisited. Philosophical Studies 125: 327-369.

Uchito, Shoko, 1997. Kanrensei riron ni okeru hanashikotoba ni arawareru shoryakubun no bunseki [An analysis of elliptical sentences occuring in speech from the perspective of relevance theory]. Bunkyo Daigaku Kokubun 26: 24-33.

Ueda, Masahi, 1995. Furiten-kun 19. Takeshoboo, Tokyo.

Ueda, Masashi, 1998. Kobochan 45. Soyosha, Tokyo.

Zaibert L., 2003. Collective intentions and collective intentionality. American Journal of Economics and Sociology 62: 209-232. 